\title{
Understanding Social Responsiveness: Portraits of practice at the University of Cape Town
}

\author{
Judy Favish and Sonwabo Ngcelwane
}

Tn 1997, the Department of Education in South Africa released its

White Paper 3: A Programme for the Transformation of Higher Education (Department of Education 1997). As part of its programme for change, the paper called on universities to contribute more directly towards national development. This policy position was reaffirmed three years later in the Department of Education's 'National Plan for Higher Education', which asserted the need to prioritise the responsiveness of academic programmes, research and community services to regional and national needs (Republic of South Africa 2001). In order to assess how institutions were managing this mandate to be more responsive, a system of institutional audits was instigated. The Higher Education Quality Committee (HEQC), established under the terms of the 1997 Higher Education Act, outlined 18 criteria against which institutions would be evaluated in the first round of institutional audits (Council on Higher Education 2004). These criteria were approved by the Council of Higher Education in 2004. The concept of 
community engagement was not defined, thus making it possible for institutions to define it in ways that were appropriate to their own contexts and missions (Council of Higher Education, 2004). In all, 23 public institutions are to be audited, and the first round is due to be completed in 2011. The University of Cape Town (UCT) was the second public university to be audited (Council on Higher Education 2006).

In tandem with these nation-wide policy developments, UCT has experienced its own emerging engagement with social responsiveness. UCT's commitment to playing an active role in South Africa's cultural, economic, political, scientific and social environment was first articulated in its mission statement of 1996 (UCT 1996). This did not, however, entail any formal reporting to the governing structure of the university on how the university was addressing major development challenges facing the country. To address that shortcoming, an ad hoc Faculty Senate Social Responsiveness Working Group (SRWG) was convened, and in 2004 UCT launched its first annual social responsiveness report (http: / / www.uct.ac.za/ services/ip/sr/anualrpts/) It was also felt that this report would assist the university to prepare for the institutional audit scheduled for 2005 .

This article traces the process of policy formulation and subsequent institutionalisation of social responsiveness at UCT and assesses that process using the criteria identified by Stanton (2007). The data comes from informal participant observation in the SRWG since 2005 and from its annual reports on social responsiveness (of which there are now five). This article outlines three aspects of institutionalisation: defining social responsiveness; linking social responsiveness to research and teaching; and supporting and rewarding social responsiveness. It finds that the participatory process used by the SRWG has laid the foundations for the institutionalisation of social responsiveness, though challenges remain with respect to ensuring a consistent implementation of the policy across the institution and maximising the impact of social responsiveness on critical challenges facing the country. 


\section{Defining social RESPonsiveness}

The first challenge the Social Responsiveness Working Group (SRWG) encountered was in stimulating a discussion about social responsiveness and coming to some university-wide understanding of its meaning. In order to do this, as a first step, the SRWG conducted an internal survey on the subject, which formed the basis of its first report. The survey was sent to 148 Heads of (Academic) Departments (HODs) and Research Units - electronically and in hard copy - as well as to individual staff members on campus. This amounted to an additional 108 copies. In total, 256 copies of the survey were sent out. There were 81 responses, amounting to a $32 \%$ return rate, which compares favourably with the return rates of other qualitative research studies at UCT. However, given that there were very few responses from several faculties, the responses did not constitute a truly representative sample of all socially responsive activities across the university.

The survey attempted to capture the ways in which staff were responding to social, economic, cultural and political development needs through their research, curriculum and choice of pedagogy. The release of the report brought to the surface very divergent views amongst the university's senior leadership about the notion of social responsiveness and the value of producing a dedicated report on the subject. Some members of the senior leadership argued that a focus on social responsiveness was necessary in order to monitor how UCT was addressing aspects of its mission which related to the stated commitment to playing an active developmental role in South Africa's cultural, economic, political, scientific and social environment (UCT 1996), and to demonstrate UCT's accountability as a public institution in helping to achieve national goals for the transformation of higher education, as outlined in the Department's White Paper 3 (Department of Education 1997). Others felt that a focus on social responsiveness could have the effect of undermining the importance of basic research, or that it could reinforce a view prevalent amongst certain stakeholders within the country that research which doesn't have an immediate impact cannot be regarded as relevant. They also argued that using the term 'responsiveness' could result in a narrow, instrumentalist view of the role of the 
university in society rather than encourage an understanding of the university as contributing to the broad public good. Amongst people sympathetic to the idea of producing an annual report there were different views about whether social responsiveness should be linked to efforts to promote social justice or whether it should also include contributions to various dimensions of development, such as cultural, economic, environmental and political (UCT 2004). A seminar was organised soon after the release of the report to debate the different views. This helped to allay some concerns, particularly those related to the need to avoid a narrow, instrumentalist approach to social responsiveness, as well as fears about attitudes to basic research. To this end, members of the SRWG stressed that policy critique should be regarded as a critical component of social responsiveness and that there was no intention to undervalue basic research. Indeed, the link between research and evidence-based policy work was explicitly recognised.

In planning the next and subsequent annual reports, the SRWG took account of the recommendation in the Audit Report of the University of Cape Town, prepared by the HEQC, which challenged UCT to 'review its current approach to community engagement (and social responsiveness) in the light of some prevailing conceptual ambiguities and quality related gaps, and work towards the development of an integrated institutions policy framework ... that would provide a more coherent set of parameters for implementation ... and quality monitoring of community engagement' (Council on Higher Education 2006, p. 37).

The SRWG decided to present the 2005 report in the form of 'descriptive case profiles'. The intention was to stimulate debate on two points: firstly, about enhancing learning and research through engagement with external constituencies; and secondly, about the role of the university in engaging with socio-economic needs. In addition, it was felt that reflection on the case studies would help the university develop an institution-wide conceptual policy framework for this aspect of the university's work, as called for in the audit report.

In identifying the descriptive case profiles, the SRWG, which was responsible for overseeing the production of the report, used the following working definition of social responsiveness: 
Scholarly-based activities that have projected and defined outcomes that match or contribute to developmental objectives or policies defined by civil society, local, provincial or national government, international agencies or industry. (UCT 2005, p. 4)

Data for the cases was collected in the form of in-depth interviews with individuals or unit/centre/ project heads. Questions for the interviews were drawn up by the SRWG. The questions covered background to the project/work/ unit; the reasons why the work was initiated; the nature of the partnerships with external constituencies; the aims of the activity; links with teaching and research; perceptions of the relationship between the socially responsive activity and the multiple purposes of higher education; the value for UCT of the activity; the nature of outputs emanating from the activity; and ideas about how social responsiveness should be evaluated and recognised by UCT (UCT 2005).

The following nine cases were covered in the 2005 Social Responsiveness Report (Favish 2006):

- Contributions to the formulation and implementation of economic policy for the motor industry

The main impact of this engagement lay in its contribution to a set of policies intended to guide the restructuring of the automotive industry to enable it to operate in a more competitive environment.

- Providing research and resources to industry: the case of the Minerals Processing Unit

The unit focuses on the provision of high-level resources to the South African mining industry through rigorous postgraduate research training, and it also conducts multi-disciplinary research into problems experienced in the industry.

- AIDS and health care modelling in the Centre for Actuarial Research

The centre is a research and teaching unit. The primary focus of the work involves developing and maintaining a model that projects the demographic impact of the AIDS epidemic in South Africa. The products of the unit are also used to assess the impact of vaccines. The unit provides information to government and civil society organisations and helps them interpret information. 
- Building the capacity of organised labour in occupational health and safety through research, advocacy, training, materials and curriculum development: the case of the Industrial Health Research Unit

This unit aims to develop the occupational health and safety capacity of trade unions and their members who can in turn use that expertise to transform the role of workers in the field of occupational health and safety. The unit's services include research on systems and practices; policy research and advocacy; providing advice to workers around injury and disease cases and their compensation claims; facilitating the development of trade union skills in case work and providing training in workplace accident investigations and health and safety audits; risk assessments; curriculum development, participatory action research; and the production of articles and reports for popular publications and academic journals.

- Mediating the interface between theory and practice to advance social justice in relation to land distribution

Professor Ntsebeza draws on his academic research to engage critically with government policy as well as with social movements on issues related to land reform. He uses research and solid evidence to back up claims and cases.

- Teaching fieldwork through community-based partnerships in the field of urban geography

Projects undertaken by the students include the mapping of public and vacant spaces that could be used for development in partnership with community organisations; the mapping of home-based businesses; analysing the ways in which factors such as age and gender differentiate residents' skills and work; and researching backyard living in Valhalla Park.

- Transforming specialist archaeological expertise into a community-based heritage and education project

Over the past ten years, this project has worked towards returning the archaeological archive to the community. It has informed the curricula for local and visiting schools and established a job creation project 'designed to generate sustainable small business built around a local archaeological record'. 
- Community service in the Faculty of Law and engagement with the legislative process

The community service part of the case describes activities which the students have initiated to meet the requirement of doing a stipulated number of hours of unremunerated community service in order to graduate. The other part of the case describes how academics get involved in legislative processes to enhance the efficacy of the criminal justice system on the basis of constitutional values.

- Shaping policy for children through evidence-based advocacy: the case of the Children's Institute

The Institute was established to harness the collective academic capability in the University to promote enquiry into the situation of children, to share this capacity through teaching and training programmes, and to mount evidence-based advocacy together with other stakeholders to influence the development of laws, policies and interventions for children.

These cases reinforced the importance of defining 'social responsiveness' in a way that allowed for the wide range of current UCT activities geared to addressing development challenges at national, provincial, local and sectoral levels. Limiting social responsiveness to the notion of community engagement, regardless of how broadly 'community' was defined, would exclude too much. As Chatterton \& Goddard (2000, p. 478) state, 'territoriality is an extremely complex and problematic concept for Higher Education Institutions [and] universities operate within multiple and overlapping territories and usually manage a portfolio of activities ranging from the global to the local'. Nor would a narrow focus on the local community encourage institutions to critically reflect on their role in regard to provincial government within the 'broader context of globalization and the resurgence of the region as an important arena for political and economic activity' (Chatterton \& Goddard 2000, p. 478). The analysis pointed to the need for UCT to define its role in relation to society in a manner that would:

- embrace the notion of being responsive to local, provincial and national needs

- encompass proactive and critical engagement of academics and students with the challenges facing society 
- include the role of higher education in fostering public dialogue about development challenges and the strategies taken by the government to address them

- include cultural, social, economic, political and environmental needs

- recognise the importance of providing students with opportunities to develop skills for active citizenship through involvement in community-based education projects.

Since 2006 the SRWG has organised three colloquia in order to reflect on issues that have surfaced in the Social Responsiveness Reports, as well as to build a community of practice around social responsiveness and equip people to promote social responsiveness within the institution. Each of the colloquia have been organised around the cases studies and have been attended by about 60 people, including people involved in the cases, union representatives, deans, deputy deans, students, heads of academic departments and other academics. The discussions in the first two colloquia focused on the definition of social responsiveness and the links between social responsiveness and the other core processes at the university.

Analysis of the contributions in these two colloquia suggested that there was consensus about using a broad definition of social responsiveness that would embody links between activities involving academic staff, external constituencies and the notion of public benefit. This latter notion was preferred because it covered the wide range of contributions being made to social, economic, cultural, political and environmental development, and did not limit the university to an instrumentalist position of responding to the needs identified by other constituencies, as the 2005 SRWG definition, given earlier, implied. However, there was strong support for retaining the term 'social responsiveness' and for emphasising the importance of responding to the local, regional and national context in our research and teaching, as there was a perceived need to counter the considerable effort being made to position the university as a world class research-led institution. This position was formally endorsed in 2006, when the Senate approved a definition of social responsiveness that stipulated that it must have an intentional public purpose or benefit (UCT 2006). 
Whilst the Senate affirmed its commitment to promoting social justice, it recognised that contributions to various dimensions of development were important. This view accords with the World Declaration of Higher Education, which states that the 'relevance in (or responsiveness of) higher education should be assessed in terms of the fit between what society expects of institutions and what they do. This requires ethical standards, political impartiality, critical capacities and, at the same time, a better articulation with the problems of society and the world of work, basing long-term orientations on societal aims and needs, including respect for cultures and environmental protection ... Higher education should reinforce its role of service to society, especially its activities aimed at eliminating poverty, intolerance, violence, illiteracy, hunger, environmental degradation, and disease' (Unesco 1998, p. 8).

Examination of the 48 cases which have been profiled over the past two years suggests a strong emphasis on promoting social justice, social reconstruction and human rights. This may be a reflection of the inequalities that characterise South African society or perhaps a bias on the part of the Deans who nominate the cases. This concern with social justice is amply illustrated by the case of London from the School of Public Health, who describes his role as an academic as 'helping to build a critical mass of researchers who can develop a coherent theoretical framework for human rights and health work, and translate this into changes in the conditions of ordinary people' (UCT 2007a, p. 22). The school's Health and Human Rights project has consciously chosen to work with 'vulnerable' groups in society such as deaf people and farm workers and to conduct their research in a manner that empowers the groups they work with to become 'agents of their own rights' through the establishment of a learning network of civil society groups that help participants develop ways to access health care, as is their right.

This concern with social justice, access and health and human rights, raises some interesting and challenging questions for public universities in South Africa, and elsewhere, as they consider their mission. Former UCT Deputy Vice-Chancellor Martin Hall has suggested that when thinking about the mission of a public university in contemporary South African society, an examination of the university's contributions to addressing poverty and growing 
inequality is critical, as these can be regarded as the biggest challenges facing the new democracy. He says: 'A necessary condition for the continued reproduction of the defining aspects of the public university is addressing inequality and its consequences' (Hall 2006, p. 2).

An analysis of the role played by the university in promoting access to higher education for groups which were previously denied such opportunities and whose social mobility was accordingly constrained, can be seen as a clear indicator of how universities can promote public benefits. Undertaking work that enables people in marginalised social groups to enter and study at the university, and enjoy the benefits of its resources, is in our view a crucial form of social responsiveness in the South African context.

The case of the Diploma in Adult Education provides an example of how previously denied sections of the community have now been granted access to higher education.

However, the case profile of several staff members from the Economics Department who collaborated with the National Treasury and international academics in a project to review South Africa's macro-economic policy illustrates a very different approach to advancing the public benefit. In this case study, three members of the School of Economics contributed to empirical research that formed the basis of reports which were produced at the end of the first phase of the project. These were then discussed with representatives from the private sector and the labour force. As one of the economists involved in the project says:

Often the things that people seem to notice with respect to social responsiveness involves work with poor people in communities. Of course that's extremely important and it makes a huge difference in its own right. But an economist like me can't do that. It's not what I do - but I can make a difference by using my disciplinary expertise to make an impact on policy, which in turn can make a big difference to the lives of ordinary people. So policy work should be seen as part of social responsiveness. (UCT 2007a, p. 33)

The definition of social responsiveness adopted by the Senate accommodates these different developmental paradigms. 


\section{LINKING SOCIAL RESPONSIVENESS TO RESEARCH AND TEACHING}

The second challenge for the SRWG in its efforts to build consensus about a framework for social responsiveness related to the widespread misconception on campus that social responsiveness referred to activities that had no relationship with research and teaching, the core processes of the university. In conceptualising the relationships of social responsiveness to research and teaching, the SRWG drew on the analysis of the cases in the Social Responsiveness Reports and comparative literature.

In 2005 a US conference, co-convened by Campus Compact and Tufts University, stated that one of its aims was to examine how research universities could 'entertain and adopt new forms of scholarship - those that link the intellectual assets of higher education institutions to solving public problems and issues' (Gibson 2006, p. 5; for more on Campus Compact see: http:// www.compact.org/). It was recognised that achieving this goal would 'necessitate the creation of a new epistemology that ... would imply a kind of action research with norms of its own, which will conflict with the norms of technical rationality - the prevailing epistemology built into research universities ... and that new forms of pedagogy and teaching will also be required' (Gibson 2006, p. 5).

This approach resonated with challenges being made to higher education institutions in South Africa to demonstrate what they were doing to rethink dominant epistemologies and generate knowledge about the third world from a third world perspective (Mbeki et al. 2005). Such an orientation would, amongst other things, require the 'conscious elucidation of an African perspective as a distinctive conceptual and analytical lens, which in turn provides a mental position or plane of projection from which the "present" is viewed, reviewed or judged, or from which propositions for new visions, or directions are made' (Odora Hoppers 2006, p. 49).

Gibbons has posited the notion of the 'agora' which comprises a 'problem-generating and problem-solving environment' (Gibbons 2006, p. 11), populated by academics and other 'publics' and designed to generate 'socially robust knowledge', that is, knowledge that will be demonstrably reliable in a broader range of contexts and not just in specific laboratory conditions (Gibbons 2006). This process usually involves a process of 'interaction between experts and others, 
each of whom may inhabit different worlds to interact effectively in transforming an issue or problem into a set of research activities' (Gibbons 2006, p. 14). Gibbons describes the issue around which they engage as a 'boundary object' and the space where engagement happens as a 'transactional' space involving two-way interaction or communication. Often, because the discussions are around problems, the solution involves interdisciplinary or transdisciplinary work (Gibbons 2006). Writers like Nyden and Gibbons argue that socially engaged research necessitates some form of community involvement in determining the research questions and the interpretation of the data.

For Nyden, collaborative university-community research typically involves partnerships in all stages of the research and dissemination of results, including conceptualisation of the issues to be studied, design of the methodology, collection of data, data analysis, writing up of a report, and dissemination of research results (Nyden 2005).

Several of the case profiles in the reports illustrate knowledge generation, knowledge application and knowledge dissemination through working with external constituencies. They show that partnerships based on principles of reciprocity, mutuality and equality can enrich the process of knowledge generation.

The portrait of the African Religious Health Assets Programme (ARHAP), located in the Department of Religious Studies, describes the use of transactional spaces involving multiple stakeholders to generate knowledge about factors impacting on the treatment of HIV / AIDS. The background to this initiative was the contestations on the ground in South Africa about the distribution of antiretrovirals (ARVs), which suggested that it is not enough to simply provide ARVs. Various etymologies of disease appeared to be at work and differing constructs of the body, health and illness were involved, many of them imbued with religious images, symbols and understandings of the world. So in working in a grounded way with communities, ARHAP tried to generate 'theories [which were] shaped as much by the way people actually think and work and live on the ground, as they were by prior learning' (UCT 2006, p. 11). ARHAP's approach is located in the body of work known as Asset Based Community Development, or capability-focused approaches, which recognises the need to take seriously the assets that people on 
the ground have, and build on these, rather than work from a deficitbased model, which is the usual approach of traditional research. As Cochrane of ARHAP says:

It is the collaboration between researchers, practitioners and local communities that generates the necessary set of new and different perspectives to create new knowledge. Academics are necessarily involved in discourses that are quite technical as a result of being influenced by particular theoretical backgrounds. But ... it is necessary to relate the discourse and the way it is constructed to the discourses that people use on the ground. As a result, there may be a need for trans-cultural interpretation. (UCT 2006, p. 11)

Other cases illustrated the potential of applying technology to improve the quality of people's lives, demonstrating a much wider notion of innovation than has been described in Northern literature on innovation to date. The Cell-Life project brought together academics from the information technology, engineering and health faculties at UCT to design a medical management system to support patients on anti-retroviral treatment by merging cell phone technology with the Internet and database systems. Similarly, the PALSA PLUS project, based in the UCT Lung Institute, was started in an attempt to address the spectrum of commonly seen lung diseases through the use of a shared, uniform approach to diagnosis and treatment in primary care settings. The work culminated in the establishment of a Knowledge Translation Unit, which promotes the integration of research findings into clinical practice so as to strengthen health services and improve patient outcomes. These two case studies demonstrate that social responsiveness work and traditional, high-level research are far from being mutually exclusive activities.

The case profiles also contain information on the variety of ways in which UCT staff seek to promote access to information and research findings, in addition to publishing in academic journals. This includes the use of websites, the production of CDs, the organisation of exhibitions and festivals, the production of posters and pamphlets, participation in radio programmes, writing newspaper articles, and presentations of papers at seminars and conferences. Indeed, as London of the Health and Human Rights project says: 
The raison d'etre of doing work on human rights is to promote the right and access to health care. So academics continuously reflect on ways of sharing information about what they learn through their research to help improve people's access to health care. (UCT 2007a, p. 23)

The cases also illustrate how academics are attempting to develop socially responsive graduates by enhancing the relevance of the curriculum through engagement with external constituencies. The portrait of the postgraduate programme in Disability Studies in the Faculty of Health Sciences illustrates how the research community of disabled and non-disabled academics, activists, policy makers and practitioners, coalesce in an 'agora' using participatory and action oriented research to generate the knowledge base of the postgraduate curriculum, as well as to inform national government policy processes. Key principles guiding the design of the course included finding an African voice for disability that could communicate the needs as identified by the Disability Rights Movement (Favish \& McMillan 2009, p. 6). This approach recognises that the university is not necessarily the only repository of knowledge, and that input from stakeholders is critical to the success of the programme. It is also based on the premise that genuine transformation cannot successfully occur through decision-making done solely by those with power, and that lasting change involves shared decision-making through the establishment of 'transactional spaces' (Gibbons 2006). This collaboration helped to ensure that the curriculum and forms of assessment were designed in a way that graduates would exit with the competencies needed to promote the rights of the disabled by ensuring a strong focus on advocacy-related skills (Favish \& McMillan 2009, p. 6).

The case of the Child Guidance Clinic describes a curriculum renewal process driven by the desire to produce psychologists equipped to work not just in private practice but also in community contexts. A crucial focus of the review was on teaching the students how to use theories in versatile ways and to think on their feet so that they are able to work in trauma contexts where groups may change every week and where it is necessary to have an immediate impact. Students are also taught how to go about identifying community resources that can provide appropriate forms of support to members 
of poor communities. The clinic is also planning to introduce a course on diversity and race related issues to equip the students to deal with these kinds of issues in therapy (UCT 2006).

The annual reports illustrate how students have benefited from service learning opportunities, where the theory they learn in the university environment is applied in a practical context, as part of the formal curriculum. However, several cases nominated by the Student Representative Council covered voluntary activities organised by student societies. This pointed to the need to ensure that the policy framework on social responsiveness accommodated civic engagement that occurred outside of the curriculum.

\section{SUPPORTING AND REWARDING SOCIAL RESPONSIVENESS}

Following Senate approval of the definition of social responsiveness in 2006, the SRWG developed a policy framework for social responsiveness, which culminated in approval by the University's Governing Council in December 2008. During this two-year period, extensive consultations took place with a range of stakeholders on campus including trade unions, student groups, support staff, faculty boards and Senate.

The policy is underpinned by a conceptual framework, reflected in the diagram below, that acknowledges the interconnectedness between social engagement and the other core activities of the university, research and teaching, as well as civic engagement, which takes place outside the formal curriculum (UCT 2008). The inclusion of civic engagement was deemed necessary as it recognised the critical role voluntary community service plays in helping to promote active citizenship among staff and students. UCT's current conceptual

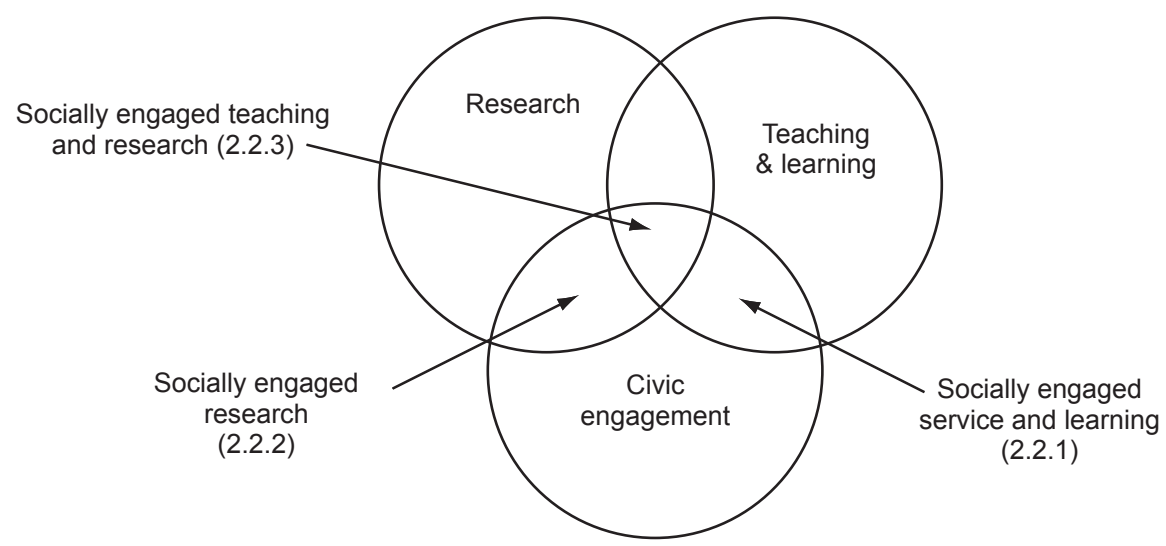


framework accordingly recognises the following major forms of social responsiveness:

- research-oriented forms of responsiveness

- teaching and learning-oriented forms of responsiveness

- civic engagement with no link to the formal curriculum.

The policy framework also identified certain functions which various units should perform in order to support staff who wish to become involved in social responsiveness. For example, the framework established executive accountability for providing university-wide leadership on social responsiveness and a Senate Committee was charged with helping to promote and strengthen social responsiveness at the university. To complement awards issued to staff and students in recognition of achievements in teaching and research, the policy framework makes provision for an institutional award for social responsiveness for staff and the issue of certificates to students who provide evidence of active involvement in civic engagement. The policy framework also makes provision for the consideration in performance reviews of staff members' contributions to social responsiveness:

Performance criteria applied in 'Rate for Job' evaluations specify that Social Responsiveness should be embedded in the three performance areas of Research, Teaching and Leadership/Management/ Administration ... This means that staff can choose to provide examples of activities related to social responsiveness as evidence of meeting the criteria in the various categories or not. (UCT 2009, p. 13)

\section{AsSESSING SOCIAL RESPONSIVENESS}

According to Hall, the outcomes of 13 audit reports completed by the HEQC between 2004 and 2008 indicate that universities in South Africa are at widely varying stages in conceptualising community engagement practice (Hall 2008). The analysis of the reports, prepared by Hall for the Council on Higher Education, led the Council to initiate a process of developing a national conceptual framework for community engagement (Hall 2008). Singh argued that the process of formulating a framework should be organised 'as a conversation between the forging of some kind of a national enabling framework and how institutions are conceptualising a next-level framework for themselves [and that this] conceptual work [should not be] about 
setting narrow, tight, exclusionary definitions of what community engagement is. [It is] rather about setting some broad parameters for community engagement in the social development agenda' (Singh 2006). The process of developing a national framework is therefore still underway in South Africa.

The HEQC has not yet published a report on all the audits conducted to date. In assessing UCT's progress with regard to social responsiveness it is not possible at this stage to compare UCT's performance with that of other institutions in South Africa or to assess our work in relation to a national framework. We have therefore chosen to assess our work in relation to criteria suggested in a report from a 2007 conference on civic engagement by research universities in the USA (Stanton 2007). This report proposes that institutionalising engagement would require the following:

- audits of institution-wide engagement to identify and assess the extent of its activity, purposes and location

- campus-wide visibility and recognition of exemplary efforts

- stimulation of debate within the university about engagement activities

- recognition of engaged scholarship in tenure and promotion decisions and grant awards

- incentives for staff and students who propose innovative courses, research and other initiatives

- appointment of staff and the establishment of capacity and infrastructure to support engagement

- educating students about the value of engaged scholarship

- the provision of sustained funding or grants for engaged scholarship and

- engagement with the university's councils and other external constituencies about the university's role and effectiveness in social responsiveness.

Assessment of developments within UCT over the past few years suggests that all but the last two criteria have been addressed, notwithstanding the fact that there is always room for further improvement.

For the past four years, UCT has been collecting information on social responsiveness activities through the process of compiling 
the annual reports. The information on these case profiles is now contained in a dedicated website maintained by the Institutional Planning Department (www.socialresponsiveness.uct.ac.za/). These reports have been used to give visibility and recognition to exemplary efforts across the campus. Three colloquia have been organised to stimulate debate within the university about social responsiveness activities. The overwhelming support for the Vice-Chancellor's draft strategic concept paper on social responsiveness, which forms part of the university's new draft strategic plan, indicates that staff no longer contest a strong focus on social responsiveness. Indeed, social responsiveness has been fully integrated into key institutional documents.

During 2007 revised criteria for performance reviews of academic staff were implemented for the first time. Social Responsiveness is embedded in the criteria, which stipulate that:

all academic staff are expected to exhibit some level of social responsiveness through teaching and learning, research and/ or leadership. At each level the onus lies on the person to demonstrate such social responsiveness of an appropriate type for this academic rank. (UCT 2007b, p. 1)

However, the SRWG was not able to ensure that examples pertinent to social responsiveness were included in the document. This was a major impediment to the efforts of the SRWG to gain recognition for staff involved in social responsiveness. Currently, analysis of faculty records indicates that several faculties are not correctly implementing the policy on the criteria for performance reviews. We suspect that this may be due either to opposition to aspects of the policy or residual confusion about aspects of the policy. The criteria are presently being reviewed. It is hoped that this will help to ensure alignment across the university with the policy framework which stipulates that, 'staff can choose to provide examples of activities related to social responsiveness as evidence of meeting the various categories (i.e. research, teaching and learning, and Leadership, Management and Administration) or not' (UCT 2009, p. 13).

Lessons can be learnt from students' commitment to their activities and the many hours they are prepared to invest in activities that do not directly benefit them in terms of their academic performance. 
Whilst the case studies involving student voluntary activities indicate the willingness and desire of students to get involved in communitybased projects, this zeal should be matched by efforts to systematically understand and articulate the outcomes, challenges and best practices in this area of work.

In terms of engaging with external constituencies about the university's role and effectiveness in social responsiveness, the annual social responsiveness reports are discussed by the university's Governing Council, but not more widely than that. For the first time, the colloquium in 2009 was organised around presentations from external constituencies and focussed on their perceptions of their partnerships with UCT. The university has also signed Memoranda of Understanding with the provincial and city governments, which are designed to strengthen collaboration around development priorities.

\section{Conclusion}

Most of the social responsiveness initiatives at UCT are happening at the level of individual academics, or units, rather than at a university-wide level. Whilst this is legitimate and desirable within universities, the complexity and urgency of the problems being addressed suggests that there may be a need for a more strategic and coordinated university-wide approach. Several critical challenges such as poverty eradication and helping to improve the quality of public schooling need to be addressed in order to maximise the impact of any interventions.

The case study on UCT's response to the xenophobia crisis in 2008 provided evidence of the need for the university 'to establish a structured mechanism to harness the intellectual resources of the university to respond to the needs of the majority of people in our country' (UCT 2009, p. 23). The Vice-Chancellor's recent strategic concept paper on social responsiveness refers to the various threats impeding efforts to construct a more democratic and just society, such as high levels of poverty and inequality, the poor quality of education in most of our public schools and the lack of infrastructure development, and proposes that UCT should appoint Pro ViceChancellors who would be able to provide more directed university leadership working in consultation with the entire university community and in liaison with organizations in communities, the city 
and province to address these needs. Such leadership would enable the university to draw on the strengths of individual departments in a coordinated fashion (UCT 2009). It is hoped that the formal approval of the strategic concept paper by the university at the end of the year will result in a more strategic institution-wide approach to social responsiveness.

\section{REFERENCES}

Chatterton, P \& Goddard, J 2000, 'The response of higher education institutions to regional needs', European Journal of Education, vol. 35, no. 4, pp. 475-496.

Council on Higher Education 2004, 'Criteria for institutional audits', Higher Education Quality Committee, Pretoria.

Council on Higher Education 2006, 'Audit report on the University of Cape Town: Report of the HEQC to the University of Cape Town', Higher Education Quality Committee, Pretoria, March 2006.

Council on Higher Education 2006, Community engagement in higher education: Proceedings of the conference, Council on Higher Education, Pretoria.

Department of Education 1997, Education White Paper 3: A programme for the transformation of higher education, Department of Education, Pretoria.

Favish, J 2006, 'Portraits of practice: Social responsiveness in teaching and research at the University of Cape Town', paper presented at the FOTIM Quality Assurance conference, Johannesburg, June 2006.

Favish, J \& McMillan, J 2009, 'The university and social responsiveness in the curriculum: a new form of scholarship?', London Review of Education, vol. 7, no. 2, pp. 169-179.

Gibbons, M 2006, 'Engagement as a core value in a mode 2 society', paper presented at the CHE-HEQC/JET-CHESP conference on Community Engagement in Higher Education, Cape Town, 3-5 September.

Gibson, CM (ed.) 2006, ‘New times demand new scholarship. Research universities and civic engagement: A leadership agenda', Campus Compact and Tufts, viewed 19 October 2009, http:/ / www.compact.org/initiatives/civic-engagement-at-research-universities/ trucen-section-a/

Hall, M 2006, 'Toward engagement for the public good', working draft, University of Massachusetts, Massachusetts.

Hall, M 2008, 'Community engagement in South African higher education', unpublished paper prepared for the Council on Higher Education, Pretoria.

Mbeki, T, Erwin, A \& Mangena, M 2005, 'The challenges facing higher education in South Africa', unpublished discussion document, Pretoria.

McMillan, J \& Pollack, S 2009, 'Taxonomy of forms of responsiveness (2005-2007)', unpublished paper presented at a workshop at the University of Cape Town, Cape Town, 22 May.

Nyden, P 2005, 'The challenges and opportunities of engaged research', paper presented at the CHE-HEQC /JET-CHESP conference on Community Engagement in Higher Education, Cape Town, 3-5 September.

Odora Hoppers, C 2006, 'Constructing a conceptual framework for HBUs in a developmental paradigm' in M Nkomo, D Swartz \& B Maja (eds), Within the realm of 
possibility. From disadvantage to development at the University of Fort Hare and the University of the North, Human Sciences Research Council, Cape Town, pp. 47-64.

Republic of South Africa 2001, 'National plan for higher education', Department of Education, Pretoria.

Stanton, TK (ed.) 2007, 'A conference report 2007. New times demand new scholarship II Research universities and civic engagement: Opportunities and challenges', University of California, Los Angeles, viewed 19 October 2009, http:/ / www.compact.org/initiatives / civic-engagement-at-research-universities/trucen-section-a/

UNESCO 1998, ‘World declaration on higher education for the twenty-first century: Vision and action', viewed 15 March 2005, http:// www.unesco.org/education/educprog/wche/ declaration eng.htm

University of Cape Town 1996, 'Mission statement', University of Cape Town, Cape Town. University of Cape Town 2004, 'Social responsiveness report 2004', University of Cape Town, Cape Town.

University of Cape Town 2005, 'Social responsiveness report 2005', University of Cape Town, Cape Town.

University of Cape Town 2006, 'Social responsiveness report 2006', University of Cape Town, Cape Town.

University of Cape Town 2007a, 'Social responsiveness report 2007', University of Cape Town, Cape Town.

University of Cape Town 2007b, 'Minimum performance criteria for academic rate for job', University of Cape Town, Cape Town.

University of Cape Town, 2008, 'Social responsiveness report 2008', University of Cape Town, Cape Town.

University of Cape Town 2009, 'Draft concept paper on social responsiveness, unpublished discussion document, Cape Town. 